chemists in industrial, government and research laboratories, including the Bureau. The steels are also available in the form of fine turnings as standards for photometric methods of analysis, as an alternative to standardization by means of pure metals. The turnings for photometric standardization are supplied in a series of eight bottles, each containing either 100,50 or $25 \mathrm{gm}$. in each. Both the rods and the turnings are obtainable direct from the Bureau of Analysed Samples, Ltd., 234 Marton Road, Middlesbrough, or through any well-known laboratory furnisher.

\section{American Committee for the Study of Alcoholism}

THE Division of Medical Sciences of the United States National Research Council has recently set up a Committee on the Problems of Alcohol to initiate and support scientific research concerned with the varied actions of alcohol as a component of the diet or as a beverage and with the special social, psychological and medical problems created by its excessive consumption. The Committee consists of fourteen persons and includes representatives from industry as well as scientific fields bearing on research into alcoholism; the chairman of the Committee is Dr. Chauncey D. Leake, vice-president of the University of Texas Medical Branch, and Dr. Joseph Hirsh, of New York University, is the executive secretary. Information on the work of the Committee, including methods of subrnitting proposals for grants in support of research on problems of alcohol, may be obtained from the Secretary, Committee on Problems of Alcohol, Division of Medical Sciences, National Research Council, 2101 Constitution Avenue N.W., Washington 25, D.C.

\section{Colonial Service : Recent Appointments}

The following appointments in the Colonial Service have recently been announced: H. K. Ashby (agricultural officer, Federation of Malaya), senior agricultural officer, Federation of Malaya; G. T. Barnes (pathologist, Fiji), pathologist, Nigeria; D. A. R. Campbell (agricultural officer, grade 2, Jamaica), senior agricultural officer, Jamaica ; H. G. Michaelides (forest assistant, Cyprus), assistant conservator of forests, Cyprus; P. E. Nesbitt (laboratory superintendent, Nigeria), senior laboratory superintendent, West African Institute, Trypanosomiasis Research, Nigeria ; W. G. Stuart (agricultural officer, grade 1, Jamaica), senior agricultural officer, Jamaica; J. R. Low, agricultural officer, Uganda; K. McKerron, agricultural officer, Aden ; J. K. B. Booth, geologist, Tanganyika; J. M. Brown, geophysicist, Geological Survey Service, Uganda; J. Dawson, S. MacDonald and A. Renwick, geologists, Federation of Malaya; A. Hatton and J. V. Hepworth, geologists, Uganda; P. N. Banks, W. D. C. Parkes and J. D. J. Ross, veterinary officers, Tanganyika; H. E. D. R Williams, veterinary officer, Trinidad; J. A. G. Glenn, game ranger, Tanganyika.

\section{Announcements}

DuRING the meeting of the British Association at Birmingham, the honorary degree of D.Se. was conferred on Sir Harold Hartley, president of the Association, at a congregation held in the Great Hall of the University on September 2.

Mr. T. C. DEnston has been appointed secretary of the British Pharmacopceia Commission in succession to Dr. C. H. Hampshire, who will retiré on October 3.

OwING to the growth of the garden work and investigations at the John Innes Horticultural Institution at Bayfordbury, it has been found necessary to separate the research and administrative sides of the Garden Department. Mr. W. J. C. Lawrence who, as curator, has been in charge of all the cultivations and research on cultivations since 1932, has been appointed to the purely research post of head of the Garden Research Department, where he will be free to continue his investigations on all aspects of indoor and outdoor cultivation. Mr. J. Newell, who has been assistant curator since 1936 , becomes curator in charge of the garden administration at Bayfordbury.

THE annual conference of the Society of Leather Trades' Chemists will be held in the University of Leeds during September 22-23. On the afternoon of September 22 the fourth Procter Memorial Lecture, for which tickets are available to non-members, will be given by Prof. E. K. Rideal, his subject being "Membrane Permeability". Further details of the conference can be obtained on application to the editorial office of the Society at Craigieburn, Duppas Hill Road, Waddon, Croydon, Surrey.

THE Industrial Applications Section of the Royal Statistical Society is organising a conference, to be held in the University of Sheffield during September 29-October 1, on "Scientific Method in Industrial Production", when technicians and managements of manufacturing concerns will be able to meet statisticians interested in industrial problems. The papers on the first day have been particularly designed for non-statistical audiences. Applications for attendance at the conference (fee 1 guinea) should be sent to the Assistant Secretary, Royal Statistical Society, 4 Portugal Street, London, W.C.2.

A SYMPosium on "High-Temperature Steels and Alloys for Gas Turbines" has been arranged by the Iron and Steel Institute and will be held under the chairmanship of Mr. J. R. Menzies.Wilson, president of the Iron and Steel Institute, in the lecture theatre of the Institution of Civil Engineers, Great George Street, London, S.W.1, during October 18-19. The provisional list of papers has been classified into the following sections: introduction, user aspects, supplier aspects, performance aspects (scaling and hot-fatigue), special casting techniques, welding aspects, special blade materials, and research and future needs. Before the symposium, the fifth Hatfield Memorial Lecture will be given by Sir Frank Whittle in the lecture theatre of the Institution of Electrical Engineers, Savoy Place, Victoria Embankment, London, W.C.2, at 8.30 p.m. on October 17 . Tickets for the symposium and Hatfield Lecture are available to non-members of the Institute. Further partieulars can be obtained from the Secretary, Iron and Steel Institute, 4 Grosvenor Gardens, London, S.W.1.

Erratum. In the communication by K. O. Müller on "Hypersensitivity and Tumour Development in Potato Tubers in Response to Infections with Phytophthora infestans" in Nature of August 5, p. 231, paragraph 1, last line, for "hypersensitive" read "hyposensitive". 